\title{
Bubonic Plague: a Brief History of Changes to Current Situation in Brazil
}

\author{
Jucier Gonçalves Júnior ${ }^{1}$, \\ Maria do Socorro Vieira dos Santos $2,3,4$, \\ João Vitor Cândido Pimentel ${ }^{1}$, \\ Cláudio Gleidiston Lima da Silva 2,3,4
}

\section{Abstract}

Plague is a globally distributed, zoonotic disease caused by the bacterium Yersinia pestis. With recurrent epidemics since the Antique, the plague ravaged the population, producing demographic, political, cultural and religious incommensurables effects. Since 1894 in Brazil, the Plague began to get closer to the federal capital through the intense commercial trading. First the Porto city, in Portugal, was attacked by the disease, after that, some neighbors' countries of the South America, like Paraguay and Argentina, and, finally, Santos, in São Paulo coast, where, for the first time in history, the disease landed in national field, in October of 1899. Data registered since 1935 reveal that the period of most intensity in the occurrence of the disease prior the 70's, declining sooner after that, verifying isolated epidemics in the 1970s, in Bahia, and 1980s, in the states of Ceará and Paraíba. Since that time, all of the foci entered a period of relative inactivity, with few or no human cases. Despite the apparent control of the Plague, the reduction or discontinuity of the vigilance, the poverty, insalubrity, frequent and out of control deforestations, urbanization, and the climate changes that alters the rodents and fleas habitat causing disequilibrium in epidemiological chain, can become influence factors in the resurgent of cases in humans.
1 Medical Students, Federal University of Cariri, Barbalha, Ceara, Brazil.

2 Faculty of Medicine, Federal University of Cariri, Barbalha, Ceara, Brazil.

3 Faculty of Medicine of $A B C$, Santo André, São Paulo, Brazil.

4 Scientific Writing Lab (LABESCl)

-Faculty of Medicine, Federal University of Cariri- UFCA

Contact information:

Maria do Socorro Vieira dos Santos.

”socorro.vieira@ufca.edu.br

Keywords

Bubonic Plague; History; Brazil.
Plague is a globally distributed, zoonotic disease caused by the bacterium Yersinia pestis [1, 2]. It is hosted by small mammals (mainly rodents) and vectored through bites from infected fleas [3]. Owing to a well-documented history of deadly pandemics that almost disrupted human civilization over the last 1,500 years, plague is often mistaken as a disease of antiquity. Contrary to this view, plague is still a major 
public health concern with widespread epidemics and isolated cases occurring in many countries of the world [4].

The $Y$. pestis is a member of the family Enterobacteriaceae, which is visualized in optic microscopy as a small Gram-negative bacillus, small, ovoid $(0,5$ to $0,8 \mu \mathrm{m}$ of diameter and from 1 to $3 \mu \mathrm{m}$ of length), with more accentuated coloration on the extremities (bipolar coloration), does not form spores, it is aerobic or facultative anaerobic, grows well in usual means at $28^{\circ} \mathrm{C}$ and $\mathrm{pH}$ between 5 and 9 . It is resistant to cold, conserving itself for a long time in cadavers and also in the exudate of fleas [5].

$Y$. pestis is a recently evolved descendent of the soil-dwelling bacillus Yersinia pseudotuberculosis, which in the course of its evolution acquired two additional plasmids (pMT1 and pPCP1) that provide it with specialized mechanisms for infiltrating mammalian hosts [6]. Thus, Y. pestis, a non-motile bacterium, first disseminates from the inoculation site (IS) into the draining lymph node (LN) after inoculation in the skin [7]. The incubation period varies from 1 to 6 days [8]. Colonization of the LN is then followed by bacterial escape into the bloodstream, resulting in septic shock and death [9]. This pathogen has several means of minimizing immune activation, with the effect that bacterial replication can proceed with minimal interference by the immune system. As a result, plague is often characterized by very high bacterial numbers in patient sera and organs [10].

The major clinical forms of plague are bubonic, pneumonic, and septic [11]. The signals and symptoms include fever, chills, general malaise, buboes (in case of bubonic form), may evolve to septicemia, meningitis, hemorrhages, disseminate intravascular coagulation, shock and, not rarely, death. It can occur, still, lung infection (pneumonic form of the disease), with severe respiratory condition, fever, dyspnea, also leading to death [8].

With recurrent epidemics since the Antique, the plague ravaged the population, producing demo- graphic, political, cultural and religious incommensurables effects [12]. Its first registers are like the "Justinian Plague" (name of the byzantine emperor of the time), having its possible origin in 532 a. C. in North of the Africa. Spread along Nile River, through the merchant route, reaching through Mediterranean Sea the city of Constantinople (Istanbul nowadays) and the Greece in final of 541 and begin of 542, beginning the pandemic that reached the north of the Africa, the Europe, Arabia and the regions of central and south Asia. It is estimated that about a half of the Byzantine Empire population was annihilated by the disease [13].

The Black Plague became famous for the devastation of more than a third of the European population between 1347 and 1353, somewhat like 25 million people (in Asia, the numbers vary from 40 to 60 million) [14]. And the nineteenth century Europeans and Americans were already used to periodical surges of plague, yellow fever and smallpox [15]. Today, in Latin America, human cases and natural foci are present in Bolivia, Brazil, Ecuador, and Peru [16].

Since 1894 in Brazil, the Plague began to get closer to the federal capital through the intense commercial trading. First the Porto city, in Portugal, was attacked by the disease, after that, some neighbors' countries of the South America, like Paraguay and Argentina, and, finally, Santos, in São Paulo coast, where, for the first time in history, the disease landed in national field, in October of 1899 [12, 17].

In 1900, the first case was related in Fortaleza, Ceará capital (Brazilian Northeast) [13]. Only in the Brazilian federal capital, Brasília, in 1900 and 1901, about five hundred individuals died. Besides of this, the Plague, which has already reached several cities of the São Paulo State, spread to others areas of the country, like São Luís of Maranhão, Porto Alegre, Recife and other cities of Rio de Janeiro state [18]. Later, between 1906 and 1907, the Plague continued to spread, establishing itself in natural focus of Northeast of Brazilian territory [13]. 
Data registered since 1935 reveal that the period of most intensity in the occurrence of the disease prior the 70's, declining sooner after that, verifying isolated epidemics in the 1970s, in Bahia, and 1980s, in the states of Ceará and Paraíba. Since that time, all of the foci entered a period of relative inactivity, with few or no human cases [17], concentrated in Bahia, being the last register, in this state, in Feira de Santana city, in 2000. After a silent period of four years, the Ceará registered the last case of the country in Pedra Branca city, in 2005 [19]. Recently published study analyzed the endemic regions to the Plague and found that fifteen out of around 580 regions (first level of the political/administrative divisions) in Latin America, or about 2.3\%, show documented presence of human plague cases. Evidence of plague was found in six out of 27 regions in Brazil (Bahia, Ceara, Minas Gerais, Paraiba, Pernambuco, Rio Grande do Norte) [16].

In this context, despite the apparent control of the Plague, the reduction or discontinuity of the vigilance, the poverty, insalubrity, frequent and out of control deforestations, urbanization, and the climate changes that alters the rodents and fleas habitat causing disequilibrium in epidemiological chain, can become influence factors in the resurgent of cases in humans. Becomes necessary, therefore, the professional capacity to the premature identification of the symptoms, the social and environmental vulnerabilities and the susceptibility to the Plague, in order to provide clarification to general population about symptoms and control measures, involving the theme of infectious diseases, the biosecurity, and the biological security, promoting not only the protection of the involved professionals, but also containing the propagation of the disease and the environmental contamination.

\section{References}

1. Dennis DT, Mead PS. Yersinia species, including plague. In: Mandell GL, Bennet JE, Dolin R, editors. Principles and practice of infectious diseases, 7th ed. Philadelphia: Elsevier; 2010. p. 2943-53.

2. Kugeler KJ, Staples JE, Hinckley AF, Gage K L, Mead PS. Epidemiology of Human Plague in the United States, 19002012. Emerging infect dis. 2015; 21(1), 16-22.

3. Bem-Ari T, Neerinckx S, Agier L, Cazelles B, Xu L, Zhang Z et al. Identification of Chinese plague foci from long-term epidemiological data. Proc Natl Acad Sci U S A. 2012; 109(21): 8196-8201.

4. Bao R, Nair MK,Tang WK,Esser L, Sadhukhan A, Holland RL et al. Structural basis for the specific recognition of dual receptors by the homopolymeric pH 6 antigen (Psa) fimbriae of Yersinia pestis. Proc Natl Acad Sci U S A. 2013; 110(3): 1065-1070.

5. Lins RHFB. Avaliação dos locos CRISPR (Clustered Regularly Interspaced Short Palindromic Repeats) em estudos epidemiológicos de cepas de Yersinia pestis [Mestrado]. Mestrado Acadêmico em Saúde Pública -Centro de Pesquisas Ageu Magalhães/Fundação Oswaldo Cruz, 2011.

6. Bos KI, Poinar HN, Schuenemann VJ, Krause J, Golding GB, Poinar $\mathrm{HN}$ et al. A draft genome of Yersinia pestis from victims of the Black Death. Nature. 2011; 478(7370): 506-510.

7. Gonzalez RJ, Weening EH, Frothingham R, Sempowski GD, Miller $\mathrm{VL}$. Bioluminescence imaging to track bacterial dissemination of Yersinia pestis using different routes of infection in mice. BMC Microbiol. 2012; 12: 147.

8. Brasil. Informe Epidemiológico CIEVS-Paraná. Departamento de vigilância e controle de agravos estratégicos -Superintendência de vigilância em saúde- Secretaria de estado da saúde do Paraná. 2012. [Acess 16 February 2015]. Available: http://www. saude.pr.gov.br/arquivos/File/InformeSE22.pdf

9. Gonzalez RJ, Lane MC, Wagner NJ, Weening EH, Miller VL. Dissemination of a Highly Virulent Pathogen: Tracking The Early Events That Define Infection. PLOS Pathog. 2015; 22; 11(1): e1004587

10. Vladimer GI, Weng D, Paquette SWM, Vanaja SK, Rathinam VAK, Aune $\mathrm{MH}$ et al. The NLRP12 inflammasome recognizes Yersinia pestis. Immunity. 2012; 37(1): 96-107.

11. Yan $Y$, Wang H, Li D, Yang $X$, Wang Z, Qi Z et al. Two-Step Source Tracing Strategy of Yersinia pestis and Its Historical Epidemiology in a Specific Region. PLoS One. 2014; 9(1): e85374.

12. aNascimento DR, Silva MAD. The bubonic plague in the city of rio de janeiro and the public strategies to combat it (19001906). Revista Territórios \& Fronteiras.2013; 6(2): 109-24.

13. Faccini-Martínez AA, Sotomayor HA. Reseña histórica de la peste en Suramérica: una enfermedad poco conocida en Colombia. Biomédica; 2013; 33(1): 8-27. 


\section{INTERNATIONAL ARCHIVES OF MEDICINE

14. Cengage Learning I. A Peste não morreu. Aventuras da História. 2013; 1(8): 1-1.

15. Almeida MAP. Epidemics in the news: Health and hygiene in the press in periods of crisis. Public Underst Sci, 2013; 22(7): 886902

16. Schneider MC, Najera P, Aldighieri S, Galan DI, Bertherat E, Ruiz A et al. Where Does Human Plague Still Persist in Latin America? PLoS Negl Trop Dis. 2014 Feb; 8(2): e2680.

17. Giles J, Peterson AT, Almeida A. Ecology and Geography of Plague Transmission Areas in Northeastern Brazil. PLoS Negl Trop Dis. 2011; 5(1): e925

18. bNascimento DR, Silva MAD. "I do not wish to be controversial": the arrival of the plague in Brazil; analysis of a controversy, 1899. Hist. cienc. saude-Manguinhos.2013; 20(1): 1271-85.

19. Saavedra RC, Dias JP. Yersinia pestis infection in the State of Bahia: effective control or epidemiological silence? Rev. Soc. Bras. Med. Trop. 2011; 44(2): 223-227

\section{Comment on this article:}

\section{(f) [in $8+\mathbf{S}$ ?}

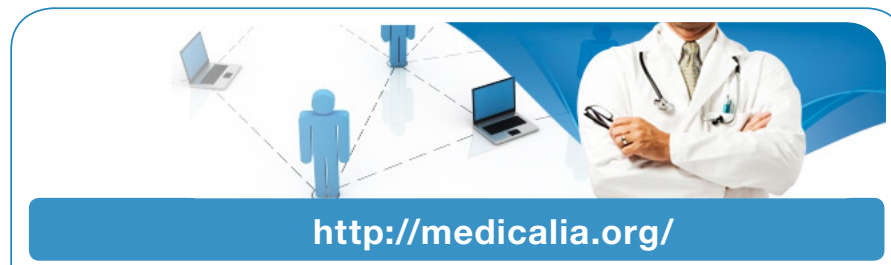

Where Doctors exchange clinical experiences, review their cases and share clinical knowledge. You can also access lots of medical publications for free. Join Now!

\section{Publish with iMedPub}

http://www.imed.pub

International Archives of Medicine is an open access journal publishing articles encompassing all aspects of medical science and clinical practice. IAM is considered a megajournal with independent sections on all areas of medicine. IAM is a really international journal with authors and board members from all around the world. The journal is widely indexed and classified Q1 in category Medicine. 